\title{
An agribusiness perspective of demonetization in central region of the state of Gujarat in India
}

\author{
Ritambhara Singh ${ }^{{ }^{*}}$ (D) and Mahesh R. Prajapati ${ }^{2}$
}

\author{
*Correspondence: \\ SinghR@aau.in; ritambhara. \\ singh@gmail.com \\ ${ }^{1}$ Department of Agribusiness \\ Economics and Policies, \\ International Agribusiness \\ Management Institute, \\ Anand Agricultural University, \\ Anand, Gujarat 388110, India \\ Full list of author information \\ is available at the end of the \\ article
}

\begin{abstract}
This paper aims at understanding the effect of demonetization announced in November 2016 on agribusiness subsystems, its effect on consumer purchasing criteria, and the problems that surfaced in rural areas to move towards digitalization. This research was exploratory in nature and so adopted an open-ended approach through interviews of 200 farmers selected from 20 villages of two districts; one economically progressive and the other economically backward, in central region of the state of Gujarat in India. Besides, 50 landless farm laborers, 12 input dealers, 20 wholesalers, 20 retailers, 4 each of processors, exporters, and logistic service providers operating in study area were also interviewed. The focus group discussions were also conducted. Secondary data were gathered from various government sources. Exploratory factor analysis was conducted to examine the consumer purchasing criteria. Garrett's ranking technique was used to find the problems of moving to digital transaction. The production activity slowed down due to immediate cash crunch. Agriculture also suffered a setback. Socio-economic factors contributed strongly to the consumer purchasing criteria postdemonetization. The rural economy worked on local credit basis during the demonetization period. Delayed sowing was observed due to non-availability of inputs during initial days of announcement of demonetization. Farm labor suffered losses. Prices of perishables crashed. More bank accounts opened in rural area as dairy payments were made mandatory through electronic mode only. Infrastructural bottlenecks, complex e-banking language and lack of technical knowhow, etc., posed problems before the rural economy to go digital. Strong policy interventions were suggested to make digitalization more popular in rural areas. Removal of infrastructural bottlenecks was suggested to absorb the shock effects of announcements like demonetization.
\end{abstract}

Keywords: Demonetization, Agribusiness, Consumer purchasing criteria, Gujarat, India, Digitalization

\section{Introduction}

On November 8, 2016 the Government of India banned ₹500 and ₹1000 notes (about $86 \%$ of the total currency in circulation, having value ₹15.44 lakh crores) to serve as a legal tender, a move what is technically known as demonetization. The notion found favors and criticism as well. The demand and supply of new notes led to decrease in demand for goods and services, widely affecting payments where paper currency was the

(c) The Author(s) 2020. This article is licensed under a Creative Commons Attribution 4.0 International License, which permits use, sharing adaptation, distribution and reproduction in any medium or format, as long as you give appropriate credit to the original author(s) and the source, provide a link to the Creative Commons licence, and indicate if changes were made. The images or other third party material in this article are included in the article's Creative Commons licence, unless indicated otherwise in a credit line to the material. If material is not included in the article's Creative Commons licence and your intended use is not permitted by statutory regulation or exceeds the permitted use, you will need to obtain permission directly from the copyright holder. To view a copy of this licence, visit http://creativeco mmons.org/licenses/by/4.0/. 
only way. In this process, 97\%, around ₹14.97 lakh crores were deposited in banks by 31 December 2016. This was not the first time when high denomination bank notes were demonetized in India. The Reserve Bank of India, country's federal bank printed highest denomination notes of ₹10,000 in 1938. Thereafter, the government demonetized ₹1000 and higher denominations in 1946. In 1954, ₹1000, 5000, and ₹10,000 were re-introduced and all of them were demonetized in 1978 to curb unaccounted money. Further, ₹500 was introduced in 1987, and ₹1000 was introduced in 2000, to contain the volume of bank notes in circulation, due to mounting pressure of price rise. It should be noted that ₹2000 was introduced for the first time in Nov 2016. Also, the history of demonetization is not restricted to India only. Several countries have had their experience with demonetization. Most of them had common objectives of curbing black money and corruption. Table 1 summarizes the details of other countries that demonetized the currency at some point in time.

The demonetization brought strong long-lasting positives and temporary negatives to countries it was announced in. The government of India took this decision on November 8, 2016 to curb India's parallel black economy (counterfeit currency), corruption and funded terrorism. Though it was assumed that siphoning off $86 \%$ of the currency in circulation may bring with it the negative impact on India's economy, the government promised that the growth will return to normal on the onset of remonetization. The secondary objective of the government behind demonetization was to accelerate the pace of digital transaction of money in India and move country towards a less-cash economy. According to the Economic Survey 2016-2017, about 78\% of all consumer payments in India happened in cash. Agriculture is one sector which is almost fully dependent on cash transactions, as it is characterized by small and marginal farmers. There are many reasons behind the use of cash in India as compared to other nations. The foremost reason why cash is favorite with Indian population is that it is convenient, accepted everywhere, and its use is costless for all segments of the society. So those who are economically backward or even ordinary people find it easy to use cash. Furthermore, cash

Table 1 Global experience on demonetization. Source: Government of India (2017)

\begin{tabular}{|c|c|c|}
\hline Countries & Objectives & Effect \\
\hline $\begin{array}{l}\text { Brazil (1990 and 1993), Ghana } \\
\text { (1982), Myanmar (1985 and 1987), } \\
\text { Russia (1993), Venezuela (2016), } \\
\text { Zimbabwe (2015) }\end{array}$ & To control hyperinflation & \multirow{9}{*}{$\begin{array}{l}\text { Positive effects } \\
\text { Banking system regained its strength } \\
\text { Gradual control over inflation } \\
\text { Stabilization of consumer prices } \\
\text { Gradual stabilization of economy } \\
\text { The inception of counterfeit-resistant } \\
\text { polymer notes in Australia } \\
\text { Negative effects } \\
\text { Loss of confidence in banking system } \\
\text { Public unrest } \\
\text { Public protest } \\
\text { Contraction of output } \\
\text { Drying of liquidity } \\
\text { Loss of jobs }\end{array}$} \\
\hline North Korea (2009) & To curb the market of black money & \\
\hline Soviet Union (1991) & $\begin{array}{l}\text { To fight against unearned income, } \\
\text { smuggling and corruption }\end{array}$ & \\
\hline Iraq (1993) & To finance fiscal deficit & \\
\hline Greece (2013) and Cyprus (2015) & To manage fiscal and banking crisis & \\
\hline $\begin{array}{l}\text { Australia (1988 and 2015) and } \\
\text { Denmark (2012) }\end{array}$ & To prevent counterfeiting & \\
\hline Euro Region (2016) & $\begin{array}{l}\text { To create common currency for } \\
\text { the EU }\end{array}$ & \\
\hline Singapore (1967,1999 and 2014) & $\begin{array}{l}\text { To mitigate high money launder- } \\
\text { ing risk }\end{array}$ & \\
\hline Pakistan (2015) & $\begin{array}{l}\text { To fight corruption and black } \\
\text { money }\end{array}$ & \\
\hline
\end{tabular}


transactions are anonymous, helping to preserve privacy, which is a virtue as long as the transactions are not illicit.

As mentioned earlier, Indian agriculture is characterized by more than $85 \%$ small and marginal farmers whose land holding vary between under one hectare and up to two hectares. Around $60 \%$ of the workforce is directly or indirectly engaged in agriculture. Most of the workers move to the urban area to work during off season. During demonetization, they faced difficulty to find work even in urban areas as the production activity slowed down due to liquidity crunch. Initial studies conducted by the National Institution for Transforming India (NITI) Ayog which is a policy think tank of the Government of India, and a few others stated that demonetization had no impact on agriculture and this conclusion was limited to only area sown under rabi crops. Aggarwal and Narayanan (2017) studied data on arrivals and prices of 35 agricultural commodities for the period 2011-2017, and focused on short-term effects up to 3 months after demonetization, tracking both the impact and recovery. They found that demonetization has displaced domestic agricultural trade in regulated markets by over $15 \%$ in short run, settling at $7 \%$ after recovery at the end of 90 days. Trade in perishables was displaced to the extent of $23 \%$ in the week following intervention, recovered, but was still $18 \%$ lower than usual. Most of this was due to decline in prices rather than arrivals, which appeared to have recovered in 3 months, the authors (Aggarwal and Narayanan 2017) concluded. Bisen et al. (2017) collected information from 40 farmers, 30 traders, and 40 consumers. The authors found that small and marginal farmers were most affected in contrast to large farmers in case of sowing, purchase and sale of agri output. Farmers dealing with perishables were more affected than those who dealt with grains. Wholesalers were more affected in grain markets and retailers in fruit and vegetable markets. Consumers used more than one mode of payment, but those with lower income and those who did not possess alternative mode of payments (e-payments) were affected most. The study found that all economic agents worked in the favor of getting normalcy at the end of February 2017. Chand and Singh (2017) analyzed agricultural growth amid demonetization within 7 weeks of intervention, on area sown, crop pattern, productivity and market. They found a delay of 1-2 weeks on sowing, but the pace later picked up. In fact area sown under wheat was higher by 7\% over last year in December. Fertilizer offtake was lesser in December, but that too later picked up when government announced the acceptance of old currency notes. No effect was found on prices of major commodities that arrive in the markets regulated by the Agricultural Produce Market Committee. However, the payments were delayed due to cash crunch. Prices of some perishables like tomato crashed in December, due to glut. Level of productivity was assumed higher due to normal NW monsoon, resulting in 10\% increase in kharif output. Damodaran (2017) found that good monsoon rains, after successive drought years, besides the timely onset of winter conducive to germination, turned out to be strong motivations for farmers to sow, even if this entailed begging or borrowing. Farmers successfully weathered the demonetization storm by simply replacing cash with deferred payments for labor, purchase of seed, fertilizer and pesticides. Prices were impacted. Potatoes in Farukkhabad in India fetched ₹350 per quintal in Feb 2017 as compared to ₹600 in the previous year. Onions in Lasangaon, Maharashtra, traded at ₹450 per quintal in May against ₹750-800 and ₹1200 in the same month of preceding 2 years. Farmers in Kolar, Karnataka, sold tomatoes in early May at ₹300-400 per quintal, down from ₹1500 to 1600 a year ago. Potatoes', onions', tomatoes' were wholesale 
priced at less than ₹5 per $\mathrm{kg}$ and their retail prices were within ₹20 per $\mathrm{kg}$. It was noted that just a $10 \%$ output increase led to $200 \%$ fall in price. Kohli (2016) found that the input purchase was affected as many purchase were outright in cash. He predicted a shortfall in acreage and productivity, and further reported $25-50 \%$ drop in sales of fruits and vegetables across markets, due to demand suppression and timely transport issues, in lack of payments and withdrawal. Srinivas (2016) said that demonetization vacuumed liquidity from the virtually cash-only economy (agriculture sector). He, in his study, found that it was a myth that farmers refused to accept cheques. Small dairy farmers in Andhra were accepting cheques, pulses, fruits and potato contract framers were accepting cheques. However, FCI (Food Corporation of India) failed to pay in cheque to Punjab and Haryana farmers because it wanted to deduct first the loan repayment amount. Direct Benefit transfer for seeds was successful even among small and marginal farmers in Uttar Pradesh. Marginal and small farmers were hit the most and so were value chains with minimal processing. The biggest argument with cash was that it is most convenient and one need not to be literate or tech-savvy to use cash. The author suggested that there is a need to push reforms. Sumathy and Savitha (2017) found that farmers faced problems as they are highly cash dependent. Daily wage earners were earning smaller amount per day. Farmers were unable to pay to the laborers, leaving laboreres jobless for months. Farmers could withdraw up to ₹25,000 per week against their crop loans to ensure sowing of winter crops. Those with no Kisan Credit Cards (KCC) were affected. Disruptions and breaks in supply chains, as sales fell, increased wastage of perishables, and lower revenues. Chopra (2016) reported that consumption slowed down of impulse and non-essential items category. Milk did not experience the impact as government relaxed purchase of milk at designated milk booths using banned denominations. Beverages, especially the alcoholic ones experienced a slowdown in sales across board. Edible oil sector experienced slowdown. The slowdown in consumption was estimated to be more prominent in cash-intensive rural markets than their urban counterparts.

None of the studies conducted, adopted agribusiness approach to understand the impact on system as a whole. This study attempts to assess the impact of demonetization from an agribusiness perspective. This study was conducted in year 2017-2018. The survey was conducted between November 2017 and December 2017. The study aimed to achieve the following specific objectives

1. To study impact of demonetization on agribusiness sub-systems

2. To examine farmers' food purchase decision criteria during pre- and post-demonetization

3. To examine the problems faced by farmers in the process of moving to a digital/cashless economy.

\section{Research methods}

The study was conducted in Central Gujarat, a state located in western region of India, for the pre- and post-demonetization period ( 1 year pre and 1 year post with effect from Nov 2016). Two districts-Anand, an economically progressive district, and Panchmahal, an economically backward district, were selected for the study. Two talukas, based 
on highest share of cultivable area to total area were selected from each of the districts. That said, Godhra and Kalol from Panchmahal and Petlad and Tarapur from Anand were selected. Five villages were selected from each of the talukas making total 20 villages for the study. In next stage, 10 farmers (of marginal, small, medium and large category) were selected using proportion to size sampling method, making a total of 200 sample farmers. Besides, 50 landless farm laborers, 12 input dealers, 20 wholesalers, 20 retailers were selected. Around four each of processors, exporters, and logistic service providers operating in study area were also covered in the study.

Primary data were collected from all stakeholders on pre-tested schedules, through interview method. To study farmers' purchasing criteria, exploratory factor analysis was carried out. The data were analyzed by using SPSS, version 20 . The factors were extracted for food items, especially fruits and vegetables in Anand and Panchmahal. Only factors with eigenvalue greater than 1 were retained and others were ignored. Parallel analysis, which is considered better than the eigenvalue criteria was also conducted to know the number of factors to be retained. Varimax rotation was used, and from the rotated matrix, factors were extracted.

\subsection{Factor analysis}

Mathematically, factor analysis is somewhat similar to multiple regression analysis, in that each variable is expressed as a linear combination of underlying factors. The amount of variance a variable shares with all other variables included in the analysis is referred to as communality. The covariation among the variables is described in terms of a small number of common factors plus a unique factor for each variable. These factors are not overtly observed. If the variables are standardized, the factor model may be represented as:

$$
\mathrm{Xi}=\mathrm{Ai}_{1} F_{1}+\mathrm{Ai}_{2} F_{2}+\mathrm{Ai}_{3} F_{3}+\ldots \ldots \ldots+\mathrm{Ai}_{\mathrm{m}} F_{m}+V_{i} U_{i},
$$

where $\mathrm{Xi}$ is the $i$ th standardized variable; Aij, the standardized multiple regression coefficient of variable $i$ on common factor $j$; $F$, the common factor; $V_{i}$, the standardized regression coefficient of variable $i$ on unique factor $U_{i}$; $U_{i}$, the unique factor for variable $i$, and $m$ is the number of common factors.

The unique factors are uncorrelated with each other and with the common factors. The common factors themselves can be expressed as linear combinations of the observed variables:

$$
\mathrm{Fi}=\mathrm{Wi}_{1} X_{1}+\mathrm{Wi}_{2} X_{2}+\mathrm{Wi}_{3} X_{3}+\ldots \ldots \ldots \ldots+\mathrm{Wi}_{k} X_{k},
$$

where Fi is the estimate of $i$ th factor; Wi, the weight or factor score coefficient, and $k$ is the number of variables.

\subsection{Garrett's ranking technique}

Garrett's ranking technique was used for promotional activities with various attributes. In the first stage, the ranking was given by farmers for each of the attributes. In the 
second stage, ranks assigned by the individual respondents were converted into percent position value by using the following formula:

$$
\text { percent position }=100(\mathrm{Rij}-0.5) / \mathrm{Nj}
$$

where Rij is the rank given for $i$ th factor by the $j$ th individual. $\mathrm{Nj}$ is for numbers of factors ranked by $j$ th individual.

In the third stage, for each percent position, scores were obtained with reference to conversation table given by Garrett and Woodworth (1969). In the fifth stage, summation of these scores for each factor was worked out for the numbers of respondents who ranked each attribute. Mean scores were calculated by dividing the total score by the numbers of respondents. In the fifth and final stage, overall ranking was obtained by assigning ranks $1,2,3 \ldots 10$ in the descending order of the mean score.

\section{Results and discussion}

\subsection{Socio-economic profile of the respondents}

Table 2 presents the socio-economic profile of the sample respondents. It reveals that most of the farmers in Anand as well as Panchmahal belonged to the age group of 46-55 years; marginal and small farmers comprised $77 \%$ of sample in Anand, while $85 \%$ in Panchmahal. Large farmers were $8 \%$ and $4 \%$ in Anand and Panchmahal, respectively.

As far as the income of the sample farmers is concerned, 25\% earned more than ₹1 lakh per annum in Anand, while only $14 \%$ belonged to this category in Panchmahal. Literacy was found more among the sample respondents from Anand as compared to Panchmahal. In Anand, the sample consisted of seven illiterates, while in Panchmahal, the number of illiterates was 22 . The study makes an attempt to associate the findings under different objectives with the socio-economic profile of the sample respondents (farmers only).

\subsection{Effect on agribusiness sub-systems}

This study assesses the effect of demonetization on agribusiness sub-systems. This section discusses in detail the input supply sub-system, production sub-system, marketing sub-system, processing sub-system, and exports.

\subsubsection{Effect on input supply sub-system}

Demonetization was announced at the time of harvest (November) of kharif season crops, ready for sale in the market and when the fields were ready for the sowing of rabi season crops. Seed, fertilizer, plant protection chemicals, irrigation, machinery and labor are the major inputs in crop production. It is to be noted that the sale of seeds and fertilizer is routed through cooperatives. Private dealers are involved in the sale of seeds and plant protection chemicals. It was found that during demonetization, the entire rural economy shifted to credit mode in Anand as well as in Panchmahal. The farmers relied on advanced purchase of inputs from the market and later, upon the sales of the harvest, made the payments. The payments for seeds and plant protection chemicals could be done immediately at the time of purchase or later upon the harvest of the crop. Generally the farmers buy the seeds and pesticides in advance on credit only. But a cash crunch 
Table 2 Socio-economic profile of the sample respondents (Farmers only). Source: Primary survey of sample respondents

\begin{tabular}{|c|c|c|c|}
\hline & Anand & Panchmahal & Tota \\
\hline \multicolumn{4}{|l|}{ 1. Age } \\
\hline 26 to 35 years & 5 & 1 & 6 \\
\hline 36 to 45 years & 39 & 36 & 75 \\
\hline 46 to 55 years & 41 & 53 & 94 \\
\hline Above 55 years & 15 & 10 & 25 \\
\hline Total & 100 & 100 & 200 \\
\hline \multicolumn{4}{|l|}{ 2. Land holding } \\
\hline Marginal ( $\leq 1$ ha) & 39 & 47 & 86 \\
\hline Small (1-2 ha) & 38 & 38 & 76 \\
\hline Medium (2-4 ha) & 15 & 11 & 26 \\
\hline Large ( $\geq 4$ ha) & 8 & 4 & 12 \\
\hline Total & 100 & 100 & 200 \\
\hline \multicolumn{4}{|l|}{ 3. Income } \\
\hline$<25,000$ & 1 & 1 & 2 \\
\hline ₹25001 to ₹50,000 & 16 & 24 & 40 \\
\hline ₹50,001 to ₹75,000 & 36 & 46 & 82 \\
\hline ₹75,001 to ₹ 100,000 & 22 & 15 & 37 \\
\hline$>$ > 100,000 & 25 & 14 & 39 \\
\hline Total & 100 & 100 & 200 \\
\hline \multicolumn{4}{|l|}{ 4. Education } \\
\hline Illiterate & 7 & 22 & 29 \\
\hline Primary & 34 & 34 & 68 \\
\hline Secondary & 24 & 27 & 51 \\
\hline Higher secondary & 19 & 13 & 32 \\
\hline Graduate & 16 & 4 & 20 \\
\hline Total & 100 & 100 & 200 \\
\hline
\end{tabular}

and delayed information flow disrupted the sales of seeds and plant protection chemicals for some time, as against the pre-demonetization phase when there were no such disruptions and therefore the farm operations were timely. However, immediate payment was required on the fertilizer purchase. That said, the sale of fertilizer was not on a credit basis. The fertilizer was sold through the cooperatives and government depots, however the payments were made in cash or through debit card. For some period, the cooperatives were accepting old currency notes. Gujarat Narmada Valley Fertilizers and Chemicals offered $10 \%$ discount on the purchase of fertilizers through debit card. At that time, the increase in cashless transaction for the purchase of fertilizer increased by around $34 \%$ as against the pre-demonetization period.

During demonetization, due to liquidity crunch, there was an immediate impact on the sale of the fertilizers and other inputs. The sample farmers revealed that it took at least a week to a fortnight to catch up with the demonetization fiasco, as they were unable to withdraw cash from banks for the purchase of fertilizers. Those who had cash, too, did not understand what to do with that as they knew that old demonetized currency was of no use. As the instructions from the government became clearer, that all the government agencies shall accept old currency notes from the farmers and that they shall not suffer on the purchase of inputs, the normalcy returned. But this itself took a week to 15 days in certain regions. The government agencies were also directed to receive cheques from 
the farmers on the sales of inputs. However, not all farmers had bank accounts to issue cheques.

The major input affected was labor, as the wages were affected due to credit crunch. The study covered landless laborers in each village (five from each village) and all of them were either without wages or work for almost a month. The payments to these laborers were delayed by a fortnight to a month. Not only this, they were also jobless for almost more than a month as the economic activities slowed in surrounding and urban areas, where they moved for daily earnings. When asked how did they met their expenses during this period, they revealed that the social structure of the village helped them to survive the odds. Laborers were given the groceries and other items on credit, provided the credibility of their job givers (medium to large farmers). Their job givers would ask the local grocery stores to provide the items of use to daily wage laborers with a promise that the payment will be done by them, later on, when the cash becomes available. Table 3 shows the detailed effect of demonetization on input supply subsystem.

\subsubsection{Effect on production sub-system}

No impact on the sowing of rabi crops was observed. Area sown initially suffered, but later the sowing picked up and increased by 6\% (over previous year) by January 2017, as per Gujarat State Seeds Corporation. The price of commodities, especially perishables such as vegetables fell down by $20-25 \%$, as against the same period during demonetization. No impact on yields was observed as the intervention was at a time when the last crop was harvested and sowing of new crop was about to begin.

\subsubsection{Effect on marketing sub-system}

Around 40 wholesalers and retailers were surveyed in the study area. Though an average estimate of the quantity bought and sold per day could not be arrived as they refused to deliver such information. However, their views on demonetization were recorded and are presented in this study.

Wholesalers and retailers form an integral part of supply chain of agricultural commodities in India. Marketing of perishables is different from that of non-perishables and requires proper supply chain intervention, in the sense that perishables need to be moved faster from producers to consumers. The selected area in this study produces chilli, tobacco, cotton, paddy (rice), tur (pigeon pea), and maize (corn) in kharif season. At the time when demonetization was announced, these crops were being harvested. While India has a mechanism of minimum support prices for cotton, paddy, tur and maize; chilli and tobacco do not enjoy the same price support. Furthermore, paddy has a set procurement mechanism. Interaction with a few traders of cereals and pulses in Anand and Panchmahal district revealed that post-demonetization, the liquidity crunch could have broken the entire economy, reducing the demand for and supply of commodities. From the demand side, as the crops were being harvested and farmers were preparing fields for next crop, a shortage of cash could have led to reduced demand for seeds and other inputs and would have impacted the acreage and production in the rabi season. But that did not happen as the close monitoring of the system prevented that to happen. On the other hand, if in the shortage of cash, the 
Table 3 Effect of demonetization on input supply sub-system. Source: Primary Survey findings

\begin{tabular}{|c|c|}
\hline \multicolumn{2}{|l|}{ a. Seed } \\
\hline Purchased from & Private dealers and cooperatives. Owned seeds were also used \\
\hline Mode of purchase & On credit and on cash. It was charged high on credit purchase \\
\hline Delay in purchase & Due to non-availability of cash, the purchase delayed by $10-15$ days \\
\hline Area sown & Impact on area sown initially. Sowing picked up later \\
\hline $\begin{array}{l}\text { Percentage farmers } \\
\text { affected }\end{array}$ & $\begin{array}{l}\text { Around } 72 \% \text { farmers in Anand reported delayed sowing and } 78 \% \text { reported the } \\
\text { same in Panchmahal (Farmers in Panchmahal generally move to urban area for } \\
\text { earning in Rabi season) }\end{array}$ \\
\hline \multicolumn{2}{|l|}{ b. Fertilizers } \\
\hline Purchased from & Fertilizer depot and Cooperatives \\
\hline Mode of purchase & Cash (old currency notes), debit cards \\
\hline Delay in purchase & 3-4 days via cash (when govt directed to accept old notes) \\
\hline Promotional offer & GNFC offered 10\% discount on the purchase of fertilizers through debit card \\
\hline Impact & Cashless transactions for the purchase of fertilizers increased by $34 \%$ \\
\hline \multicolumn{2}{|l|}{ c. Plant protection } \\
\hline Purchased from & Private dealers \\
\hline Mode of purchase & On credit and on cash \\
\hline Delay in purchase & Due to non-availability of cash, the purchase delayed by $10-15$ days, in line with sowing \\
\hline \multicolumn{2}{|l|}{ d. Credit } \\
\hline Loan taken & 18\% sample farmers had taken crop loan during kharif 2016-17 \\
\hline $\begin{array}{l}\text { No. of Bank accounts } \\
\text { opened }\end{array}$ & $\begin{array}{l}\text { 15\% sample farmers in Anand, and 34\% farmers in Panchmahal applied for bank } \\
\text { account post-demonetization } \\
\text { All those who had dairy animals including landless laborers had to mandato- } \\
\text { rily register for bank accounts. } 75 \% \text { of landless laborers also applied for bank } \\
\text { accounts post-demonetization }\end{array}$ \\
\hline \multicolumn{2}{|l|}{ e. Labor } \\
\hline Availability and Demand & Ample availability, less demand \\
\hline Mode of payments & $\begin{array}{l}\text { Cash. Due to cash crunch, work scarcity. No one was willing to lend them. All bor- } \\
\text { rowing from locals was based on personal relations }\end{array}$ \\
\hline Delayed payments & 1 week to 15 days. Payment was done in parts \\
\hline Substituted by & Family \\
\hline
\end{tabular}

buyers would offer low price to the farmer for the harvested produce, the farmers' would rather wish to hold the produce back and wait for better prices. Therefore, the supply and demand crunch would lead to a crash in arrivals and prices to a greater extent. That said, holding back and waiting for a better price is possible with farmers having large volumes and, certainly of a non-perishable crop. If farmers hold the crops for prices getting better, the other option that is left with them is to purchase on credit. The survey of selected villages revealed that there was extreme shortage of cash as against the pre-demonetization period. As a result, the entire village economy shifted on a credit mechanism. As mentioned earlier in the input supply segment, the marketing of commodities, especially perishables was also affected. The price crashed (Table 4). It was revealed that the larger and distant markets faced supply crunch, while the smaller and nearer markets had supplies. In some cases, the traders sent the vehicles to the villages and loaded the commodities paying the farmer either through cheque or they were transacting on credit. This had a greater impact on consumption and savings of the farmer. The cheques would take time to be encashed as the banks 
were already burdened. The major impact that was observed on the wholesalers and retailers could be summarized as follows:

1. The payments to the farmers were delayed by a week to a fortnight as the traders were short of cash

2. They, therefore were too transacting on credit.

3. Payments to cotton, tobacco and paddy farmers were done through cheque.

4. In case of grains and pulses, wholesalers were more affected while in case of fruits and vegetables, retailers were more affected.

\subsubsection{Effect on logistic providers, exporters and processors}

During demonetization, exporters faced the problems regarding payment to farmers and laborers. This was due to non-availability of new currency. The payments to the farmers and laborers were delayed by a fortnight to a month. Even though the exporters managed to pay farmers through cheque, payments to the laborers was delayed for long, more so in absence of their bank accounts. Before demonetization, they used to pay farmers within 1 week and to laborers on daily basis. Though their routine activities were not affected because all the stakeholders supported each other, and agreed to manage the currency crisis.

There was an impact on processing as plant capacities were not utilized. There was a $10-15 \%$ cut in capacity utilization due to sluggish demand, unavailability of labor and raw material. However, export centric production units did not suffer. It was found that the payments to daily wage earners/laborers engaged in these units were done through cheque on a fortnight basis.

Logistic providers were not affected while making toll payments or making payment at fuel stations, as old currency notes were accepted at both places-toll plazas and fuel stations. However, they too faced trouble in making payments to laborers.

Table 4 Price of selected commodities in the month when demonetization was announced (Nov 2016) vis-a-vis corresponding month in Nov 15 and Nov 17. Source: Primary Survey

\begin{tabular}{|c|c|c|c|}
\hline Kharif harvest & Nov 15 (₹/Qtl) & Nov 16 (₹/Qtl) & Nov 17 (₹/Qtl) \\
\hline Okra (lady finger) & 2213.33 & 1841.67 & 2250.00 \\
\hline Bittergourd & 1940.00 & 1431.25 & 2107.00 \\
\hline Capsicum & 3875.00 & 2571.43 & NA \\
\hline Bottlegourd & 1267.46 & 537.05 & 1308.00 \\
\hline Cauliflower & 1758.52 & 997.67 & 1795.00 \\
\hline Chilli & 1100.00 & 650.00 & 1750.00 \\
\hline Delayed sales & \multicolumn{3}{|c|}{$\begin{array}{l}\text { A week to a fortnight, post-harvest losses increased for perishables. Retailers of } \\
\text { perishables were more affected }\end{array}$} \\
\hline Payments made & \multicolumn{3}{|c|}{$\begin{array}{l}\text { Payments to cotton, tobacco, and paddy farmers since demonetization were made } \\
\text { through cheque mode }\end{array}$} \\
\hline
\end{tabular}




\subsubsection{Infrastructural bottlenecks before less cash economy}

Bank branches, agricultural credit societies, and automated teller machine (ATM) are present in a periphery of $5-10 \mathrm{~km}$ in Anand while more than $10 \mathrm{~km}$ in Panchmahal. Low penetration of smartphone among farming communities was observed. Farmers revealed that there were less telecommunication facilities (towers) in hilly region of Panchmahal.

\subsection{Farmers' purchasing criteria during pre- and post-demonetization}

The study also assessed the purchasing criteria of farmers for food and non-food items during pre- and post-demonetization. Fruits and vegetables, foodgrains and pulses, milk and milk products, and processed products are the general food item categories that any Indian household having vegetarian diets would purchase. Out of these, the demand for milk is inelastic in nature, when it has to be compared with the changes in price. In a rural household, of all the food categories, mentioned here, it was found that the daily purchase items are in general fruits and vegetables and milk and milk products. Foodgrains and pulses are purchased once in a year, to be used for the rest of the days in that year. In case of processed products, the rural households do not buy and consume processed products to the extent they are consumed in the urban households. The survey revealed that among processed food items category, farmers generally bought cooking oil and that too in bulk. Other processed products were not found to be of any importance either during pre- or post-demonetization. Most of the sample farmers had dairy animals at home. So their demand for milk was met by the product availability at home. Farmers, generally were not found purchasing milk for consumption. Even those who did not keep dairy animals, their demand for milk was met by the local exchange of products in kind from neighboring farmers. Fruits and vegetables was found the only category, which was purchased by the farmers on a regular basis. Therefore, this study was limited to examine the purchasing criteria for fruits and vegetables only, among the food items category. It was found that farmers stopped the purchase of non- essentials temporarily (giving no importance to any of them, but health, and light and fuel which were to be purchased or not to be avoided as and when needed). The study therefore did not cover the non-food items.

\subsubsection{Factors affecting food purchase decision in Anand}

The relative importance of various food purchasing criteria was estimated for fruits and vegetables for 16 parameters on 1-5 scale (1 indicated "not at all important" and 5 indicated as "extremely important") for Anand and Panchmahal. Factor analysis was performed using all 16 parameters. The analysis was done separately for Anand and Panchmahal, for pre- and post-demonetization period. The results are presented through Tables 5, 6, 7, 8, 9 and 10. Based on mean scores, the five most important parameters that respondents rated very highly for food purchasing decisions for fruits and vegetables in Anand, pre-demonetization (Pre-DeMO) were: seasonality, locally produced, good for health, freshness and affordability. Post-demonetization (Post-DeMo), in Anand, locally produced, personally known to shopkeeper, family size, affordability and seasonality were the top five decision-making criteria (Table 5). 
Bartlett's test of sphericity and the Kaiser-Meyer-Olkin (KMO) test of sample adequacy are the pre-requisites for conducting exploratory factor analysis. it was note that the $\mathrm{p}$ value for the Bartlett's test for the recorded data for all variables during Pre-DeMo and Post-DeMo was below 0.05, suggesting that the correlation matrix was significantly different from an identity matrix. The Kaiser-Meyer-Olkin test of sample adequacy was conducted to check whether the sample collected was adequate. Its value was found to be more than 0.70 for Pre-DeMo and Post-DeMo for Anand, which indicated that the datasets have sufficient items for each factor and therefore could be used for factor analysis (Tables 6 and 7). Hair et al. (2010) suggested that if the Kaiser-Meyer-Olkin test value is greater than 0.6 and Bartlett's test of sphericity is significant, then the dataset is suitable for factor analysis.

With a valid Bartlett and KMO test score, exploratory factor analysis was conducted on data sets. For this study, the principal component method was used. A parallel analysis is considered best than the eigenvalue criteria to retain the number of factors, so a parallel analysis was also conducted to identify the number of factors to be retained.

The parallel analysis results suggested five factors should be retained during Pre-DeMo for Anand, and thus the study proceeded with the factor analysis using five factors. All coefficients $\leq 0.40$ were suppressed. The rotation method used in this study was varimax. Table 8 presents the factor loadings for the five-factor solution.

Table 8 explains that in Anand, in case of fruits and vegetables, about $72 \%$ of total variance in the data set was explained by five-factor solution during Pre-DeMo. The variables-seasonality, overall quality, nearby availability and locally produced were loaded on first factor that contributed the most i.e. $22.75 \%$ to the total variance. Value for money, color, taste, and freshness were loaded on second factor contributing $18.25 \%$ to the total variance. Personal relationship with the shopkeeper and the promotional offers were loaded on third factor contributing $15.11 \%$. Socio-economic variables like affordability

Table 5 Relative importance of fruits and vegetables purchasing decision criteria by sample farmers in Anand district

\begin{tabular}{llll}
\hline Pre-demonetization (Pre-DeMo) & & Post-demonetization (Post-DeMo) & \\
\hline Seasonality & 4.25 & Locally produced & 4.68 \\
Good for health & 4.2 & Personal relationship with shopkeeper & 4.56 \\
Locally produced & 4.17 & Family size & 4.4 \\
Freshness & 4.16 & Affordability & 4.24 \\
Affordability & 4.1 & Seasonality & 4.17 \\
Family size & 4.09 & Value for money & 4.15 \\
Value for money & 3.98 & Good for health & 4.13 \\
Promotional offer & 3.96 & Freshness & 3.76 \\
Cleanliness & 3.94 & Promotional offer & 3.69 \\
Personal relationship with shopkeeper & 3.5 & Cleanliness & 3.29 \\
Overall quality & 3.17 & Taste & 3.22 \\
Taste & 3.14 & Nearby availability & 2.96 \\
Nearby availability & 2.89 & Variety of products availability at same place & 2.91 \\
Variety of products availability at same place & 2.69 & Overall quality & 2.5 \\
Good ambience & 2.34 & Cleanliness & 2.3 \\
Color & 2.15 & Color & 2.14
\end{tabular}

1 indicates "not at all important" and 5 indicates as "extremely important" 
Table 6 KMO and Bartlett's test (Pre-DeMo, Anand)

\begin{tabular}{lll}
\hline Kaiser-Meyer-Olkin measure of sampling adequacy & & 0.797 \\
Bartlett's test of sphericity & Approx. Chi-square & 620.205 \\
& Df & 66 \\
& Sig. & 0.000
\end{tabular}

Table 7 KMO and Bartlett's test (Post-DeMo, Anand)

\begin{tabular}{|c|c|c|}
\hline \multicolumn{2}{|c|}{ Kaiser-Meyer-Olkin measure of sampling adequacy. } & 0.790 \\
\hline \multirow[t]{3}{*}{ Bartlett's test of sphericity } & Approx. Chi-square & 271.622 \\
\hline & Df & 66 \\
\hline & Sig. & 0.000 \\
\hline
\end{tabular}

Table 8 Pre-demonetization factor loading for various purchasing decision criteria for fruits and vegetables-Anand

\begin{tabular}{|c|c|c|c|c|c|}
\hline & 1 & 2 & 3 & 4 & 5 \\
\hline Seasonality & 0.721 & & & & \\
\hline Overall quality & 0.71 & & & & \\
\hline Nearby availability & 0.639 & & & & \\
\hline Locally produced & 0.522 & & & & \\
\hline Value for money & & 0.789 & & & \\
\hline Freshness & & 0.667 & & & \\
\hline Taste & & 0.658 & & & \\
\hline Color & & 0.502 & & & \\
\hline $\begin{array}{l}\text { Personally relation- } \\
\text { ship with shop- } \\
\text { keeper }\end{array}$ & & & 0.759 & & \\
\hline Promotional offer & & & 0.741 & & \\
\hline Affordability & & & & 0.812 & \\
\hline Family size & & & & 0.809 & \\
\hline $\begin{array}{l}\text { Variety of products } \\
\text { availability at same } \\
\text { place }\end{array}$ & & & & & 0.895 \\
\hline Good ambience & & & & & 0.792 \\
\hline Cleanliness & & & & & 0.748 \\
\hline \multicolumn{6}{|l|}{ Good for Health } \\
\hline $\begin{array}{l}\text { Total variance } \\
\text { explained (per } \\
\text { cent) }\end{array}$ & 22.75 & 18.25 & 15.11 & 10.87 & 5.12 \\
\hline $\begin{array}{l}\text { Cumulative variance } \\
\text { (per cent) }\end{array}$ & 22.75 & 41.00 & 56.11 & 66.98 & 72.10 \\
\hline Cronbach's alpha & 0.898 & 0.828 & 0.791 & 0.828 & 0.787 \\
\hline
\end{tabular}

Extraction method: principal component analysis with varimax rotation

and family size were loaded on fourth factor contributing $10.87 \%$ and good ambience, cleanliness and variety of products availability at same place, all of which could be summarized as place of sale were loaded on fifth factor and contributed $5.12 \%$ to the total variance. The scale reliability test was also conducted using Cronbach's alpha. The value of alpha above 0.70 revealed that the scale was reliable. 
Table 9 Post-demonetization factor loading for various purchasing decision criteria for fruits and vegetables-Anand

\begin{tabular}{|c|c|c|c|c|c|}
\hline & 1 & 2 & 3 & 4 & 5 \\
\hline Affordability & 0.766 & & & & \\
\hline Family size & 0.678 & & & & \\
\hline Seasonality & & 0.793 & & & \\
\hline Locally produced & & 0.745 & & & \\
\hline Nearby availability & & 0.698 & & & \\
\hline Overall quality & & 0.567 & & & \\
\hline Value for money & & & 0.786 & & \\
\hline Freshness & & & 0.645 & & \\
\hline Promotional offer & & & & 0.823 & \\
\hline Personal relationship with shopkeeper & & & & 0.67 & \\
\hline \multicolumn{6}{|l|}{ Color } \\
\hline \multicolumn{6}{|l|}{ Taste } \\
\hline \multicolumn{6}{|l|}{ Good for health } \\
\hline Variety of products availability at same place & & & & & 0.797 \\
\hline Good ambience & & & & & 0.676 \\
\hline Cleanliness & & & & & 0.57 \\
\hline Total variance explained (per cent) & 20.75 & 18.10 & 17.84 & 12.98 & 9.35 \\
\hline Cumulative variance (per cent) & 20.75 & 38.85 & 56.69 & 69.67 & 79.02 \\
\hline Cronbach's alpha & 0.882 & 0.86 & 0.78 & 0.743 & 0.702 \\
\hline
\end{tabular}

Extraction method: principal component analysis with varimax rotation

Table 10 Relative importance of food purchasing decision criteria of fruits and vegetables in Panchmahal

\begin{tabular}{llll}
\hline Pre-demonetization & & Post-demonetization & \\
\hline Locally produced & 4.25 & Affordability & 4.25 \\
Seasonality & 4.20 & Seasonality & 4.10 \\
Affordability & 4.14 & Locally produced & 3.98 \\
Family size & 3.93 & Family size & 3.84 \\
Value for money & 3.87 & Value for money & 3.62 \\
Nearby availability & 3.67 & Personal relationship with shopkeeper & 3.55 \\
Freshness & 3.40 & Variety of products availability at same place & 3.33 \\
Personal relationship with shopkeeper & 3.14 & Promotional offer & 3.07 \\
Good for health & 2.98 & Good for health & 3.02 \\
Cleanliness & 2.95 & Freshness & 2.87 \\
Variety of products availability at same place & 2.75 & Cleanliness & 2.84 \\
Overall quality & 2.30 & Overall quality & 2.53 \\
Color & 2.24 & Nearby availability & 2.47 \\
Taste & 2.02 & Taste & 2.42 \\
Promotional offer & 1.95 & Color & 1.82 \\
Good ambience & 1.85 & Good ambience & 1.8 \\
\hline
\end{tabular}

1 indicates "not at all important" and 5 indicates as "extremely important" 
Table 11 KMO and Bartlett's test (Pre-DeMo, Panchmahal)

\begin{tabular}{lll}
\hline Kaiser-Meyer-Olkin measure of sampling adequacy & & 0.755 \\
Bartlett's test of sphericity & Approx. Chi-square & 240.164 \\
& Df & 66 \\
& Sig. & 0.000 \\
\hline
\end{tabular}

Table 12 KMO and Bartlett's test (Post-DeMo, Panchmahal)

\begin{tabular}{|c|c|c|}
\hline \multicolumn{2}{|c|}{ Kaiser-Meyer-Olkin measure of sampling adequacy. } & 0.646 \\
\hline Bartlett's test of sphericity & Approx. Chi-square & 185.867 \\
\hline & Df & 66 \\
\hline & Sig. & 0.000 \\
\hline
\end{tabular}

Post-demonetization (Table 9) around 79\% of total variance was explained by five-factor solution, when it comes to the purchasing decision criteria of fruits and vegetables in Anand district. As against being the fourth factor to contribute to the purchasing behavior socio-economic variables i.e. affordability and family size were loaded on first factor during post-demonetization period. The variance explained by this factor was $20.75 \%$, almost double to pre-demonization period (factor 4, 10.87\%). The variables that loaded on factor one pre-demonetization, loaded on factor 2 post-demonetization contributing $18 \%$ to total variance. Variety of products available at same place, good ambience and cleanliness defining the place of sale loaded on fifth factor post-demonetization as well, however explained more variance (9.35) than pre-demonetization (5.21). Interesting thing to note is that personal relationship with shopkeeper and promotional offers loaded on fourth factor post-demonetization contributing around $13 \%$ to total variance. The scale reliability test was also conducted using Cronbach's alpha. The value of alpha above 0.70 revealed that the scale was reliable.

\subsubsection{Factors affecting food purchase decision in Panchmahal}

Based on mean score, the five most important parameters, pre-demonetization in Panchmahal were locally produced, seasonality, affordability, family size and value for money. Post-demonetization, the five parameters in order of importance were affordability, seasonality, locally produced, family size, and value for money (Table 10). It is to be noted that Panchmahal is an economically backward district.

Again, the $\mathrm{p}$ value for Bartlett's test of sphericity for all variables during Pre-DeMo and Post-DeMO was found below 0.05 the value of Kaiser-Meyer-Olkin test of sample adequacy was found to be more than 0.70 for both Pre-DeMo and Post-DeMO, which indicated that the dataset was suitable for factor analysis (Tables 11 and 12).

Factor analysis was performed using all the above parameters important for buying decisions, About $69.55 \%$ of total variance in the data set was explained by the six factor solution during Pre-demonetization (Table 13) and around $71 \%$ was explained by six factors during post-demonetization (Table 14).

The scale reliability test was also conducted using Cronbach's alpha. The value of alpha above 0.70 revealed that the scale was reliable. 
Seasonality, nearby availability, locally produced, and overall quality loaded on factor 1 and contributed $20 \%$ to total variance in pre-demonetization phase while they loaded on factor 4 and contributed $11.56 \%$ in post-demonetization phase. Family size and affordability loaded on factor two during both pre- and post-demonetization contributing 15.50 and $15.75 \%$ to total variance, respectively. Value for money and freshness of the product loaded on factor 3 during both pre- and post-demonetization and contributed 12.35 and $13.50 \%$ to total variance, respectively. Personal relationship with the shopkeeper and promotional offers loaded on factor 4 and contributed 9.92\% during pre-demonetization, while they loaded on factor 1 and contributed $19.75 \%$ to total variance post-demonetization. It could be due to the fact that Panchmahal district is economically backward and therefore the farmers here relied more on personal relationships and promotional offers in post-demonetization phase when liquidity crunch was observed. It was interesting to know that in case of Panchmahal, taste, color and health were loaded on factor 6 during both pre- and post-demonetization indicating the less importance of these variables in making purchasing decisions regarding fruits and vegetables.

Table 13 Pre-demonetization factor loading for various purchasing decision criteria for fruits and vegetables_-Panchmahal

\begin{tabular}{|c|c|c|c|c|c|c|}
\hline & 1 & 2 & 3 & 4 & 5 & 6 \\
\hline Seasonality & 0.717 & & & & & \\
\hline $\begin{array}{l}\text { Nearby avail- } \\
\text { ability }\end{array}$ & 0.704 & & & & & \\
\hline Locally produced & 0.689 & & & & & \\
\hline Overall quality & 0.675 & & & & & \\
\hline Family size & & 0.821 & & & & \\
\hline Affordability & & 0.765 & & & & \\
\hline Value for money & & & 0.758 & & & \\
\hline Freshness & & & 0.713 & & & \\
\hline $\begin{array}{l}\text { Personal relation- } \\
\text { ship with } \\
\text { shopkeeper }\end{array}$ & & & & 0.706 & & \\
\hline Promotional offer & & & & 0.808 & & \\
\hline Cleanliness & & & & & 0.78 & \\
\hline $\begin{array}{l}\text { Variety of prod- } \\
\text { ucts availability } \\
\text { at same place }\end{array}$ & & & & & 0.89 & \\
\hline \multicolumn{7}{|l|}{ Good ambience } \\
\hline Taste & & & & & & 0.80 \\
\hline Good for health & & & & & & 0.656 \\
\hline Color & & & & & & 0.55 \\
\hline $\begin{array}{l}\text { Total variance } \\
\text { explained (per } \\
\text { cent) }\end{array}$ & 20.12 & 15.5 & 12.35 & 9.92 & 6.09 & 5.57 \\
\hline $\begin{array}{l}\text { Cumulative vari- } \\
\text { ance (per cent) }\end{array}$ & 20.12 & 35.62 & 47.97 & 57.89 & 63.98 & 69.55 \\
\hline Cronbach's alpha & 0.857 & 0.81 & 0.776 & 0.787 & 0.698 & 0.734 \\
\hline
\end{tabular}

Extraction method: principal component analysis with varimax rotation 
Table 14 Post-demonetization factor loading for various purchasing decision criteria for fruits and vegetables-Panchmahal

\begin{tabular}{|c|c|c|c|c|c|c|}
\hline & 1 & 2 & 3 & 4 & 5 & 6 \\
\hline Promotional offer & 0.765 & & & & & \\
\hline Personal relationship with shopkeeper & 0.622 & & & & & \\
\hline Affordability & & 0.789 & & & & \\
\hline Family size & & 0.813 & & & & \\
\hline Value for money & & & 0.837 & & & \\
\hline Freshness & & & 0.765 & & & \\
\hline Nearby availability & & & & 0.65 & & \\
\hline Locally produced & & & & 0.766 & & \\
\hline Overall quality & & & & 0.754 & & \\
\hline Seasonality & & & & 0.728 & & \\
\hline Variety of products availability at same place & & & & & 0.764 & \\
\hline \multicolumn{7}{|l|}{ Good ambience } \\
\hline Cleanliness & & & & & 0.648 & \\
\hline Good for health & & & & & & 0.734 \\
\hline Color & & & & & & 0.562 \\
\hline Taste & & & & & & 0.504 \\
\hline Total variance explained (per cent) & 19.75 & 15.75 & 13.5 & 11.56 & 5.65 & 4.42 \\
\hline Cumulative variance (per cent) & 19.75 & 35.5 & 49 & 60.56 & 66.21 & 70.63 \\
\hline Cronbach's alpha & 0.852 & 0.823 & 0.785 & 0.76 & 0.706 & 0.697 \\
\hline
\end{tabular}

Extraction method: principal component analysis with varimax rotation

\subsection{Problems of moving to a digital/cashless economy}

As it is mentioned in the beginning that the secondary objective of demonetization was to reduce the cash transactions and enhance digital or cashless transactions to discourage illegal practices in the monetary transactions in the country which in turn will bring transparency in the money transactions, curbing corruption, and funding to terrorism through several illegal routes. Coming back to the agricultural economy, then it is to be understood that agriculture is a sector where majority of the transactions for input purchase or selling of output happen in cash. This study attempted to analyze the intensity of problems faced by farmers to move to a digital/cashless economy. The survey tried to explore the preparedness of farming community, to do cashless/digital transactions. The Indian banks introduced Kisan Credit Cards (KCC) in 1998 to provide for term loans and agricultural needs. KCC credit card holders are covered under personal accident insurance up to ₹50,000 for death and permanent disability, and up to ₹25,000 for other risks. Despite this, it was found that farmers were not utilizing it. Farmers were not availing this facility to full extent. When asked about the use of Kisan Credit Cards, debit cards or accessing the internet and mobile banking facility, farmers showed their resistance to practice the existing methods of digital/cashless transactions, due to lack of technical knowhow. Table 15 reveals the problems faced by the respondents in selected area to move towards digitalization, and are ranked in the order of intensity as obtained through Garrett score. It was noted that in Anand, technical knowhow required for digital transactions emerged as a major problem, followed by language of banking system (English, with which the farmers were not comfortable). It was followed by illiteracy or low education, the awareness related to digitalization (low or absent in some farmers), 
and other problems in order as mentioned in Table 15. As far as the district of Panchmahal is concerned, awareness related to digitalization was the foremost problem, followed by illiteracy or low education, technical knowhow, language of banking system, etc.

Digitalization in rural area did not catch the pace, in terms of internet or mobile banking, as there was lack of technical knowhow among rural communities and they were at ease in cash transactions. Even the educated farmers had no idea of using technology. Language of banking system acted as another major barrier. Digital transactions, suffered significant impediments. Digitalization requires special equipments, cellphones for customers and point of sale (PoS) terminal for merchants. A PoS terminal is an electronic device used to process card payments. Only two shops in villages of Anand were found having PoS terminal but they too were nonfunctional as the associated charges were higher. It was found that after a year of demonetization, the economy in villages was back to fully cash transactions. A very important component on digitalization are cellphone with features enabled and smartphones. These two are also not finding place in the lives of farmers due to lack of technical knowhow. It is a challenge before the government as to infuse the willingness and technical knowhow among the farmers and rural population as such to adopt digitalization.

\section{Conclusions}

Demonetization was promoted as a drive to fight corruption and terrorism, two of the strongest problems the country faced. Hence, when announced, the public, in good numbers came forward to support the decision. This was despite the fact that the rural economy suffered a setback, as the study revealed. Although, the system adjusted to the shocks, the slowdown affected the production and consumption activities, employment and prices too. The social fabric in India is strong so people helped each other and the entire village economy survived on interest-free credit. The study revealed that the cash crunch and long waiting time in banks to exchange demonetized currency, caused production as well as consumption delays. The purchase of the agricultural inputs was delayed by a fortnight to a month, even though the Government asked the input agencies to accept old currency notes and cheque for the supply of fertilizers. Farm wages were affected as labor faced payment delays and work shortage for about one to 2 months. Prices and arrivals of the commodities were also affected. The study revealed that the price of harvested commodities fell substantially

Table 15 Problems faced by farmers for moving to cashless/digital economy

\begin{tabular}{|c|c|c|c|c|c|}
\hline \multirow[t]{2}{*}{ S. no. } & \multirow[t]{2}{*}{ Problems } & \multicolumn{2}{|l|}{ Anand } & \multicolumn{2}{|l|}{ Panchmahal } \\
\hline & & $\begin{array}{l}\text { Mean Garrett } \\
\text { Score }\end{array}$ & Rank & $\begin{array}{l}\text { Mean Garrett } \\
\text { Score }\end{array}$ & Rank \\
\hline A & Awareness about digitalization & 53.76 & IV & 72.73 & 1 \\
\hline B & Language of banking system & 73.20 & $\|$ & 57.47 & IV \\
\hline C & Technical knowhow & 75.08 & 1 & 60.39 & III \\
\hline$E$ & $\begin{array}{l}\text { Transactions of small amount (to be } \\
\text { done by cash only) }\end{array}$ & 42.75 & $\mathrm{VI}$ & 38.02 & VI \\
\hline G & Facility not available in small stores & 44.79 & V & 38.22 & V \\
\hline $\mathrm{H}$ & Illiteracy or low education & 58.78 & III & 68.44 & $\|$ \\
\hline
\end{tabular}


over corresponding period in the previous year. Retailers of perishable commodities were affected more as the less consumer demand led to fall in prices, and their profit margins reduced. It was noted that traders made payments for cotton, tobacco, and paddy crops through cheque. Exporters and processors were able to manage their processing plants and export consignments, as the mode of transaction was generally cheque, even though there were initial delays in utilizing the plant capacity. However, they were less affected than other players in the system. Broken supply chains were found in the study area and it is therefore felt that with right infrastructure in place, farm sufferings could have been minimized. Furthermore, broken supply chains led to low price realization by farmers. The signs of distress sale were visible, though it was temporary (about a month). The post-harvest losses increased at retailers' level. Reduction in consumer demand affected the sales at retail level. Farmers' purchasing behavior of food items was affected more by socio-economic factors (family size and affordability as in case of Anand) and new offering post-demonetization (promotional offers and personal relationships as in case of Panchmahal). This was different from pre-demonetization period where seasonality, quality and availability were the major variables affecting purchase both in Anand and Panchmahal district.

On a brighter note, demonetization brought some changes for good. To promote digitalization was secondary objective of demonetization, and the study found that there was a rise in the opening of bank accounts and e-payments. The system was made more effective and transparent by linking the unique identity number "Aadhar" with bank accounts, and mobile numbers. However, the extent of digital transactions was found poor and may be improved. There were infrastructural bottlenecks that made the situation difficult. The findings from the study suggested that infrastructural bottlenecks must be removed with opening of bank branches, establishment of more ATMs and introduction of cold storage facilities for perishables. Banks should come forward, to conduct training programs and educate and encourage farming community to adopt digital measures. Easy apps in regional languages could act as a catalyst to enhance digital transaction among rural population. Government should come forward to announce some price support programs for perishables or make necessary arrangements to make sure that the income of farmers is not affected during such policy announcements.

\section{Abbreviations}

NITI: National Institution for Transforming India; KCC: Kisan Credit Card; ATM: Automated teller machine; PoS: Point of sale.

\section{Acknowledgements}

Not applicable.

\section{Authors' contributions}

The first author visualized the concept of this research, prepared interview schedules, surveyed, analyzed and prepared this paper. The second author did the survey, data punching, and analysis. Both authors read and approved the final manuscript.

\section{Authors' information}

Dr. Ritambhara Singh is currently working as Assistant Professor in the Department of Agribusiness Economics and Policies in the International Agribusiness Management Institute of the Anand Agricultural University, Anand, Gujarat, India. She has total work experience of 14 years with organizations of repute, including FAS-USDA, MCX India Ltd, etc. Dr. Singh holds a Ph.D. in Agricultural Economics with a minor in Statistics from Govind Ballabh Pant University of Agriculture and Technology, Pantnagar, India. She is the life member of several professional bodies, and has around 50 academic and industrial publications to her credit, including articles in news dailies. Her research areas are Agribusiness, Macroeconomics, International Trade, Supply Chain, Climate Change issues, and Price and Trade policy. 
Dr. Mahesh R. Prajapati holds M.Com in Finance and Accounting and M. Phil. and Ph. D in Commerce and is presently working as an Assistant Professor and Head in Department of Financial Management, International Agribusiness Management Institute, Anand Agricultural University, Anand, Gujarat, India. He has a total work experience of 11 years in teaching and research. His areas of interest are Managerial Accounting, Financial Management, Financial markets and services. He has around 15 published research papers/articles to his credit. He is life member of Indian Accounting Association and Indian Commerce Association.

\section{Funding}

No funding received.

\section{Availability of data and materials}

The datasets used and/or analyzed during the current study are available from the corresponding author on reasonable request.

\section{Competing interests}

The authors declare that there are no competing interests.

\section{Author details}

${ }^{1}$ Department of Agribusiness Economics and Policies, International Agribusiness Management Institute, Anand Agricultural University, Anand, Gujarat 388110, India. ${ }^{2}$ Department of Financial Management, International Agribusiness Management Institute, Anand Agricultural University, Anand, Gujarat 388110, India.

Received: 22 August 2019 Revised: 29 March 2020 Accepted: 4 August 2020

Published online: 24 August 2020

\section{References}

Aggarwal N, Narayanan S (2017) Impact of India's demonetization on domestic Agricultural Markets. In: Working Paper. Indira Gandhi Institute of Development Research, Mumbai. http://www.igidr.ac.in/pdf/publication/WP-2017-023. pdf. Accessed 24 Jan 2018

Bisen J, Kumar S, Venkatesh P, Aditya KS (2017) Impact of demonetization on agriculture: a case study. Ind J Econ Dev 5(2):1-11

Chand R, Singh J (2017) Agricultural Growth in the Aftermath of Demonetization. In: Publications. Niti Ayog, New Delhi. https://www.niti.gov.in/writereaddata/files/document_publication/Demonetisation_Agriculture_Blog.pdf. Accessed 28 Jan 2018

Chopra V (2016) Demonetization: A Bolt out of the Blue. Rabobank, India. https://research.rabobank.com/far/en/sectors/ regional-food-agri/Demonetisation-A-Bolt-out-of-the-Blue.html?gsl_reqcnt=1. Accessed 7 Dec 2017

Damodaran H (2017) The crops of wrath. In: Indian Express. https://indianexpress.com/article/opinion/columns/thecrops-of-wrath-demonetisation-4699598. Accessed 8 Aug 2018

Garrett HE, Woodworth RS (1969) Statistics in psychology and education. Vakils, Feffer and Simons Pvt. Ltd., Bombay

Government of India (2017) Economic Survey 2016-17. Economics Division, Ministry of Finance, Department of Economic Affairs, New Delhi

Hair JF, William CB, Barry JB, Rolph EA (2010) Multivariate data analysis: a global perspective, 7th edn. Pearson, New York Kohli R (2016) Demonetization: the impact on agriculture. In: Livemint. https://www.livemint.com/Opinion/B1vFTOgwqH jdM5nkmg2CxJ/Demonetization-The-impact-on-agriculture.html. Accessed 28 Jan 2018

Srinivas NN (2016) How Demonetization has affected India's Food and Agricultural Markets: Myths versus reality. In: Huffingtonpost. https://www.huffingtonpost.in/nidhi-nath-srinivas/how-demonetisation-has-affected-indias-agric ultural-and-food-ma_a_21608078/. Accessed 28 Jan 2018

Sumathy VG, Savitha T (2017) Impact of demonetization on agriculture sector. J Humanities Soc Sci 1:35-38

\section{Publisher's Note}

Springer Nature remains neutral with regard to jurisdictional claims in published maps and institutional affiliations.

\section{Submit your manuscript to a SpringerOpen ${ }^{\circ}$ journal and benefit from:}

- Convenient online submission

- Rigorous peer review

- Open access: articles freely available online

- High visibility within the field

- Retaining the copyright to your article

Submit your next manuscript at $\boldsymbol{s p r i n g e r o p e n . c o m ~}$ 